\title{
Are Asians Black?: The Asian-American Civil Rights Agenda and the Contemporary Significance of the Black/White Paradigm
}

\author{
Janine Young Kim
}

\section{INTRODUCTION}

The phrase "civil rights movement" evokes the powerful words and images of the mass movement by Black Americans in the United States during the 1950s and 1960s. In recent years, however, Asian Americans have increasingly laid claim to a place in the history of the struggle for civil rights. Just as Derrick Bell harkens back to Dred Scott v. Sanford ${ }^{1}$ as the first of the "leading cases" in civil rights, ${ }^{2}$ Hyung-Chan Kim's anthology of Asian-American civil rights cases and essays recalls cases such as Yick Wo v. Hopkins ${ }^{3}$ as proof of Asian Americans' longstanding participation in the development of civil rights law in the United States. ${ }^{4}$

When tensions within American multicultural, multiracial society exploded in Los Angeles in 1992, not only history but immediate reality itself seemed to insist on the inclusion of Asian Americans within the larger discourse on civil rights. Because what began as an arguably Black (Rodney King)-White (LAPD officers) conflict transformed into multiracial strife involving not only Black and White Americans but also Latinos and Asian Americans, the riots brought into sharp relief the complex racial interrelationships within Los Angeles. As a result, two race scholars announced that the riots "marked the beginning of a new period of U.S. racial politics," 5 one that must "decisively break with the bipolar model of

1. 60 U.S. (19 How.) 393 (1857).

2. See Civil RIGHTS: LEADING CASES 1 (Derrick A. Bell, Jr. ed., 1980).

3. 118 U.S. 356 (1886).

4. See ASIAN AMERICANS AND THE SUPREME COURT: A DOCUMENTARY HISTORY 27-29 (Hyung-Chan Kim ed., 1992).

5. MiCHAEL OMI \& HOWARD WINANT, RACIAL FORMATION IN THE UNITED STATES 145 (2d ed. 1994). 
race." ${ }^{6}$ Since then, the black/white paradigm has been a subject of increasing academic debate; the controversy has likely entered the popular consciousness as well, due to the highly publicized conflict between Angela $\mathrm{Oh}$ and John Hope Franklin within President Clinton's race relations commission. $^{\text {? }}$

Although existing legal scholarship on the black/white paradigm generally assumes the paradigm to be a biracial model of racism that focuses exclusively on the relationship between Black and White Americans, ${ }^{8}$ an explicit definition is rare and difficult to find. ${ }^{9}$ The dearth of legal scholarship that endeavors to outline the contours of the black/white paradigm is problematic not only because the inadequacy of the paradigm is an often unexplored and unchallenged assumption, but also because the assumption may be incorrect or misleading.

This Note focuses on the (uneasy) relationship between the black/white paradigm and the Asian-American civil rights agenda. My primary project is to intervene in the seemingly unproblematic discussion of the black/white paradigm in order to caution that current race discourse oversimplifies the

6. Id. at 154-55. Professors Omi and Winant also note that the riots "served to focus media attention on generally neglected racial/ethnic subjects-Koreans, Central Americans, Chicanoswho were both victims and victimizers." Id. at 153 .

7. When Angela $\mathrm{Oh}$ argued that the commission should look "beyond" the black/white paradigm, John Hope Franklin is reported to have resisted that suggestion by replying that " ' $[\mathrm{t}] \mathrm{his}$ country cut its eyeteeth on racism in the black-white sphere." Gregg Zoroya, Beautiful Dreamer, L.A. TMEs., Feb. 1, 1998 (Magazine), at 10 (citation omitted); see also Sam Fulwood III \& Doyle McManus, Panel on Race Urges Nothing but More Talk, L.A. TMMES, Sept. 18, 1998, at Al (reporting that the question of the commission's focus proved divisive); Warren P. Strobel, Panelists Argue over What To Focus on, WASH. TIMES, Sept. 21, 1997, at A8 (describing the conflict as a "healthy tension ... not always pretty to watch").

In this Note, I use the lowercase form of "black" and "white" where the terms are used theoretically, politically, and figuratively.

8. See OMI \& WINANT, supra note 5, at 152 ("U.S. society is racially both more diverse and more complex today than at any previous time in its history. Racial theory must address this reality...."); John O. Calmore, Our Private Obsession, Our Public Sin: Exploring Michael Omi's "Messy" Real World of Race: An Essay for "Naked People Longing to Swim Free," 15 LAW \& INEQ. J. 25, 56-57 (1997) (relying on demographic data to demonstrate the declining relevance of the black/white paradigm); Robert S. Chang, Toward an Asian American Legal Scholarship: Critical Race Theory, Post-Structuralism, and Narrative Space, 1 ASIAN L.J. 1, 27 (1994) ("[C]ritical race scholarship tends to focus on the black-white racial paradigm, excluding Asian Americans and other racial minorities."); Juan F. Perea, The Black/White Binary Paradigm of Race: The "Normal Science" of American Racial Thought, 85 CAL. L. REV. 1213, 1215 (1997) ("It is precisely my position as a Latino outsider, neither Black nor White, that makes possible the observation and critique presented in this Article."); Deborah Ramirez, Multicultural Empowerment: It's Not Just Black and White Anymore, 47 STAN. L. REv. 957, 959 (1995) (alluding to the fallacy of the Kerner Commission's conclusion that "Our nation is moving toward two societies, one black, one white-separate and unequal") (quoting REPORT OF THE NATIONAL ADVISORY COMMISSION ON CIVIL DISORDERS 1 (1968)); William R. Tamayo, When the "Coloreds" are Neither Black nor Citizens: The United States Civil Rights Movement and Global Migration, 2 ASIAN L.J. 1 (1995) (advocating a new theory to replace the current biracial vision).

9. Juan Perea has also noted that the black/white paradigm is not well discussed in legal literature. See Perea, supra note 8, at 1214. He, of course, constitutes a major exception to that statement. 
paradigm and fails to articulate the full cost of its abandonment. One reason for my argument is that a paradigm once so powerful should not, as a principle, be discarded without serious analysis. A second, more compelling, reason is that the black/white paradigm retains contemporary significance despite demographic changes in American society. It is, therefore, imperative that race scholars understand the paradigm's enduring resonance and potential before concluding that it nevertheless ought to be abandoned. It is my belief, however, that the paradigm is important to the Asian-American civil rights agenda today and that to eliminate it from race discourse would mean losing an important tool for living in and understanding our evolving, racially stratified society.

Part II of this Note very briefly summarizes some scholarship on the black/white paradigm and questions the boundaries and assumptions embedded within the scholarship. Part III clarifies my own assumptions about race and race relationships-namely that they are constructed and therefore unstable-and identifies six dimensions of the black/white paradigm. These six dimensions, through which I attempt to (re)define the black/white paradigm, are elaborated in Part IV. Finally, Part V is devoted to addressing the objection that the black/white paradigm is inapplicable to the Asian-American civil rights agenda by analyzing immigrants' rights and affirmative action through the lens of the paradigm as I envision it.

\section{II. “BLACK/WHITE”: SCHOLARSHIP ON THE PARADIGM}

Condemnation of the black/white paradigm is usually premised on the argument that the nation is no longer Black and White but multiracial, such that the paradigm has become obsolete. This critique of the black/white paradigm suggests that many scholars reduce the black/white paradigm to serve a purely descriptive function; the paradigm was acceptable in 1960 when ninety-six percent of the minority population was Black, but now that Black Americans constitute only fifty percent of the people of color, the paradigm can no longer stand. ${ }^{10}$

While the descriptive function is a significant aspect of the black/white paradigm, it is not the paradigm's only, nor its most important, function. Thus, a rejection of the paradigm based solely on its apparent failure to reflect racial demographics underestimates its sophistication and fails to explain its longevity. Recent race scholarship by Asian-American and Latino/a scholars has relied on this oversimplified, descriptive version of the black/white paradigm. ${ }^{11}$ The works of Robert Chang, a leading AsianAmerican race theorist, and Juan Perea, a Latino scholar who has grappled

10. See Ramirez, supra note 8 , at 962 .

11. See supra note 8 and accompanying text. 
directly with the "dominant and pervasive character" of the black/white paradigm, are particularly thoughtful. ${ }^{12}$ Still, neither Professor Chang nor Professor Perea takes the discussion of the paradigm much further than Michael Omi and Howard Winant's seminal work on the racial formation theory and their 1994 critique of the black/white bipolar model. ${ }^{13}$ This Part will summarize these scholars' representations of the black/white paradigm and question some of their assumptions and prescriptions.

\section{A. Omi and Winant and the Los Angeles Riots}

Michael Omi and Howard Winant's project in Racial Formation in the United States is to explore the construction of race. They argue that race is not essential, but social and political; the concept of race can and is transformed through political struggle and sociohistorical processes generally. ${ }^{14}$ They call this continual process of constructing and reconstructing race "racial formation." 15 The theory of racial formation embraces the notion that race is not merely a classificatory system based on the distinctions among human bodies at any given moment, but that it also contains traces of past struggle over, and present understanding of, social and political relationships. ${ }^{16}$

In the epilogue to the second edition of Racial Formation in the United States, written after the 1992 Los Angeles riots, Professors Omi and Winant seem to address the prevalence of the black/white paradigm. ${ }^{17}$ They reject the project of dichotomizing race and identify five problems in the black/white conception..$^{18}$ First, they argue that the complex nature of race relations must be analyzed in light of changing dynamics within and among racial groups. Second, they suggest that biracial theories ignore issues specific to non-Black, non-White racial groups. Third, in a related point, they argue that biracial theories also ignore the different consequences of policies such as affirmative action or welfare to different racial groups. Fourth, they assert that the black/white model overlooks "particularities of contemporary racial politics" such as nativism. ${ }^{19}$ Finally, they posit that the model marginalizes or eliminates other-non-Black, non-White-voices in race discourse.

12. Perea, supra note 8, at 1214.

13. See OMI \& WINANT, supra note 5.

14. See id. at 55 .

15. $I d$.

16. See id. at $55-61$.

17. See id. at 152-55. It should be noted that Professors Omi and Winant do not actually employ the word "paradigm" but alternately use terms such as "model," "conception," "vision," and "theory." Id.

18. See id. at 153-54.

19. Id. at 154. 
These critiques provide important insights, but Professors Omi and Winant clearly indicate that their critiques are aimed at biracial theorizing because the privileging of the Black-White relationship ignores "widespread and multiracial discontent." ${ }^{20}$ There is, however, a difference between a focus on the Black-White relationship and the black/white paradigm, and Professors Omi and Winant's discussion does not clarify to which they object.

\section{B. Juan Perea and Race Paradigms}

Juan Perea's The Black/White Binary Paradigm of Race: The "Normal Science" of American Racial Thought $t^{21}$ can be seen as an extension of the discussion Professors Omi and Winant began in Racial Formation. Professor Perea attempts to prove the existence of the black/white paradigm by applying Thomas Kuhn's study of paradigms to race discourse. ${ }^{22}$ Professor Perea finds that even as paradigms help us to frame knowledge, they also exclude and distort by defining, and thus limiting, relevancy. ${ }^{23}$ Accordingly, he defines the black/white paradigm as "the conception that race in America consists, either exclusively or primarily, of only two constituent racial groups, the Black and the White." ${ }^{24}$ Professor Perea then documents the ways in which the black/white binary paradigm has excluded the experiences and struggles of Latinos and other non-Black, non-White groups by examining textbooks and history books that purport to deal with the race problem in general but focus primarily on the struggles of the African-American population. ${ }^{25}$

Professor Perea focuses largely on the effect of the black/white paradigm on scholarship and "normal research" on race. ${ }^{26}$ I emphatically agree with Professor Perea that the absence or marginalization in scholarship of other racialized groups such as Latinos, Asian Americans, and Native Americans is harmful not only to these groups, but to the richness of race discourse in general. But I disagree with his suggestion that the black/white paradigm has an unimportant role in forming or understanding the racial identities and positions of non-White, non-Black groups and individuals ${ }^{27}$ because, as I attempt to demonstrate in Part IV, the

20. Id. at 153 .

21. Perea, supra note 8.

22. See id. at 1216-21 (citing ThOMAs S. KuHN, THE STRUCTURE OF SCIENTIFIC REVOLUTIONS (2d ed. 1970).

23. See Perea, supra note 8, at 1216-18.

24. Id. at 1219.

25. See id. at 1221-52.

26. Id at 1219.

27. See id. at 1220. 
black/white paradigm is more sophisticated than Professor Perea's narrow, race-specific definition of it.

Moreover, the ultimate purpose of Professor Perea's discussion remains somewhat confusing. He states that he opposes the use of paradigms and instead advocates the development of an inclusive and particularized understanding of race. ${ }^{28}$ Although he denies that his "new understanding" of race is another paradigm, it is not clear how or why it manages not to be one. $^{29}$

\section{Robert Chang and a Theory of Asian American Legal Scholarship}

Within Asian-American legal academia, Robert Chang has been one of the most vocal scholars in denouncing the paradigm as "inadequate" to address the concerns of the Asian-American community. His article, Toward an Asian American Legal Scholarship: Critical Race Theory, PostStructuralism, and Narrative Space, ${ }^{30}$ suggests themes and theories of Asian-American legal scholarship, offering a generalized perspective on the direction that the scholarship should take. One of the most noteworthy sections in his article is Professor Chang's critique of the current racial paradigm, which he identifies as the black/white paradigm. Professor Chang claims to analyze the paradigm on two levels. First, on the level of lived reality, he observes that the color of the American population has become variegated in the last four decades. He calls this conflict between the black/white paradigm and demographic transformations a "problem of coverage." ${ }^{31}$ Second, Professor Chang argues (in a maneuver that conflates the black/white paradigm with the civil rights movement) that the theory and philosophy of the traditional civil rights movement-that is, its focus on individual rights-is antithetical to many Asian philosophies of noself. ${ }^{32}$

Unfortunately, Professor Chang's short critique (about six paragraphs) of the current racial paradigm begs more questions about the author's assumptions than it answers. For example, he does not explain why the black/white paradigm should be identified with traditional civil rights work, and he fails to defend his assertion that traditional civil rights is indeed

\footnotetext{
28. See id. at 1256.
}

29. Professor Perea's thesis is weak for another reason. Although the early sections of his article seemed to lead to a final, radical demand that the history and experience of groups such as Asian Americans, Latinos, and Native Americans be included in race/civil rights scholarship, Professor Perea ends by merely objecting to the inference that scholarship on the Black/White relationship addresses American racism in its totality. See id. at 1254.

30. Chang, supra note 8.

31. Id. at 26.

32. For other Asian American legal scholars who take a similar two-tiered approach to the black/white paradigm, see Tamayo, supra note 8; and Frank Wu, Neither Black nor White: Asian Americans and Affirmative Action, 15 B.C. THIRD WORLD L.J. 225 (1995). 
centrally concerned with individual rights as opposed to group rights or equal protection. ${ }^{33}$ Moreover, he glosses over the unverified and essentializing notion that Asian Americans share a no-self worldview that is theoretically opposed to individual rights.

Although Professor Chang writes about Asian-American civil rights on two levels, his main critique of the traditional civil rights movement and the contemporary dominance of the black/white paradigm is devoted to the problem of coverage. He forcefully argues that the black/white paradigm "misunderstands" the racial situation in the United States because race hierarchy has "more than just a top and a bottom." ${ }^{34}$ By framing the argument in this way, Professor Chang implies that Asian Americans fall somewhere in the middle of the race hierarchy. On the other hand, such an understanding tends to confuse his own position on the "model-minority myth," which he claims is a "complimentary façade ... [that] works a dual harm by (1) denying the existence of present-day discrimination against Asian Americans and the present-day effects of past discrimination, and (2) legitimizing the oppression of other racial minorities and poor whites." ${ }^{35}$ If indeed the "model-minority" is a façade and race hierarchy is not bipolar, where or how are Asian Americans situated in the racial landscape? Although he denies the black/white paradigm a place in Asian-American legal scholarship, Professor Chang does not offer an answer to this question.

\section{III. “BLACK/WHITE” : THE MEANING AND IMPACT OF THE PARADIGM}

The Judge: But now, why do you refer to you people as blacks? Why not brown people? I mean you people are more brown than black.

Biko: In the same way as I think white people are more pink than white. ${ }^{36}$

A shared assumption among Professors Omi, Winant, Perea, and Chang is that the black/white paradigm is a race-specific, descriptive model of race in the United States. The new conventional wisdom seems to be that (at least) "yellow," "brown," and "red" need to be included in order for race discourse to be inclusive and effective towards the eradication of discrimination. In other words, these critics of the black/white paradigm

33. Professors Omi and Winant, on the other hand, have suggested that the focus on individual rights and remedies, as well as color-blind racial policy, are a deliberate neoconservative strategy of the 1970s and 1980s. See OMI \& WINANT, supra note 5, at 70.

34. Chang, supra note 8 , at 27.

35. Id. at 20.

36. DONALD WOODS, BIKO 165 (1978). 
emphatically declare that yellow, brown, and red are neither black nor white.

One problem with this view of the black/white paradigm is that it considers only one of the paradigm's many dimensions. As Gary Okihiro has noted (in the context of speaking about Asian Americans), the simple question of whether yellow is black or white or neither encompasses many other more complex questions: questions of American identity, Asian American identity, third-world identity, the relationships among people of color, and the nature of American racial formation. ${ }^{37}$ I would add that the question of black or white is also explicitly a question of the accumulation and concatenation of social and cultural symbols and meanings about race, at any given moment, recognizing that such symbols and meanings continually change. This view reflects the "constructedness" of racialized individuals and groups in society.

Race scholars in the United States have explored extensively the social and legal construction of race. Professors Omi and Winant's racial formation theory is one prominent example of an anti-essentialist perspective on the "social nature of race." ${ }^{38}$ Ian Haney López has taken the racial formations theory further and examined the legal construction of race by analyzing citizenship and naturalization cases that attempted to define "white" with confusing and contradictory results, especially as whiteness related to Asians and Latinos. ${ }^{39}$ With this project, Professor Haney López destabilizes whiteness by exploring some of the biological and anthropological alternatives that American law and society considered in its attempt to circumscribe racial privilege. He writes that "race is highly contingent, specific to times, places, and situations. ... [H] and however deeply a part of our society race may be, races are still only human inventions." ${ }^{40}$ Hence, to recognize the "constructedness" of race is also to understand that "black" and "white" may signify more than our immediate understanding of specific racial categories. Professor Haney López's examination of the racial prerequisite cases of the late nineteenth and first half of the twentieth centuries reveals that "white" does not simply stand for members of the White race, but for a set of concepts and privileges associated with that race. Accordingly, "black" is defined by the denial of those same privileges. ${ }^{41}$

37. See GARY OKIHIRO, MARgINS AND MAINSTREAMS: AsIANS IN AMERICAN HISTORY AND CULTURE 33 (1994).

38. OMI \& WINANT, supra note 5, at 4.

39. See IAN F. HANEY LÓPEZ, WHTTE BY LAW: THE LEGAL CONSTRUCTION OF RACE (1996).

40. $I d$. at xiii-xiv.

41. This conception of "black" and "white" can also be found in Adrienne Davis's analysis of Hudgins v. Wrights, 11 Va. (1 Hen. \& M.) 134 (1806). In Hudgins, three enslaved women sought to be declared free by claiming Native American status. According to Professor Davis, at the core of the racialized slave system existed White anxiety about being mistakenly enslaved; 
Thus, the black/white paradigm is rife with complexities that reach beyond the races for which the words "black" and "white" stand. There are at least six significant dimensions to the black/white paradigm: (1) descriptive; (2) theoretical; (3) political; (4) historical; (5) linguistic/poetic; and (6) subversive. The descriptive dimension is the most limiting because of its association with specific races, although, as I argue in Part IV, there is more even to the descriptive dimension than critics of the paradigm acknowledge. But it is the theoretical dimension of the black/white paradigm that reveals the paradigm's full scope as well as its possibilities. Recognition of these various dimensions is important for the AsianAmerican civil rights agenda and legal scholarship because they reveal where and how Asian Americans are situated within American racial structure and suggest openings for collective, counter-hegemonic discourse.

Although the six dimensions are presented more or less discretely below, they are, in fact, interdependent aspects of the paradigm. Each must be fleshed out and examined before rejection of the paradigm can be justified. On the other hand, such an investigation may lead to a revitalization of the black/white paradigm for the Asian-American civil rights agenda.

\section{THE SIX DIMENSIONS OF THE BLACK/WHITE PARADIGM}

\section{A. The Descriptive Dimension}

There are two ways in which the black/white paradigm could occupy a descriptive role in race discourse. The first and more facile would be to view the black/white paradigm as descriptive of the relationship between two specific races: "black" signifying African Americans and possibly West Indians, and "white" signifying European Americans. This descriptive definition is of central importance in Professors Chang's and Perea's articles, as well as in Professors Omi and Winant's book. If the black/white paradigm's sole purpose is to reflect racial demographics, it would be truly false and underinclusive, rendering invisible Asians, Latinos, Native Americans, and other groups in race discourse. In that case, the paradigm would indeed suffer from a problem of "coverage" by failing to understand and incorporate the experiences of other groups that also contend with racism and discrimination. ${ }^{42}$ Another harmful effect of a racespecific paradigm would be its ratification of the notion that only the relationship between Blacks and Whites matters. This is the starting point

hence the development of a strong association, and legal presumption, between slavery and blackness, freedom and whiteness. See Adrienne Davis, Identity Notes Part One: Playing in the Light, 45 AM. U. L. REV. 695, 702-09 (1996).

42. See supra notes $30-35$ and accompanying text. 
for Professor Perea's critique of the black/white paradigm as expressed in textbooks and history books that do not document the struggles of Asian Americans, Latinos, or Native Americans while purporting to write about race and civil rights history in general. In this way, both Professor Chang and Professor Perea are attempting to discuss what they perceive to be certain groups' fundamentally existential crisis in race discourse in the United States.

This definition is, however, too limited and superficial. A more complex aspect of the descriptive dimension of the black/white paradigm is its reflection of racial stratification and conceptualization in the United States. ${ }^{43}$ This more complex descriptive dimension is implicit in both Professors Chang's and Perea's discussions of the black/white paradigm's persistence in race discourse. Racial conceptualization and stratification in the United States are dominated by the notion that "black" and "white" are positioned at opposite extremes that denote race oppression and privilege.

The black/white structure may exist in the form that it does because of the priority in time of racial discrimination against Blacks or because of the sheer virulence of racism targeting Blacks, thereby rendering the Black American experience most salient. Regardless of how the paradigm came about, it is undeniably one of the chief mechanisms by which individuals and groups become racialized, and even self-identify, on both legal and social/cultural planes. One example of how Asian Americans have been racialized according to the black/white paradigm can be found in People $v$. $\mathrm{Hall}^{44}$ a case that nullified a Chinese witness's testimony under a law that prohibited Blacks, Mulattos, and Indians from testifying in trials involving White defendants. In that decision, the court determined that "Black" included all non-Whites. ${ }^{45}$ An event of self-identification within the black/white paradigm occurred in Hudgins v. Wrights, ${ }^{46}$ a case that illustrates how slavery laws constructed "black" to be almost synonymous with "enslavement" in 1806, prompting three Native American women to declare themselves not black. ${ }^{47}$ Finally, Professor Haney López's analysis of the racial prerequisite cases demonstrates that both dynamics can occur simultaneously through legal and social pressures. "White" in the late nineteenth and early twentieth centuries meant citizenship, and individuals of Asian ancestry attempted to define themselves as "white" in order to naturalize and acquire the rights attendant to citizenship. ${ }^{48}$ But because

43. John Calmore identifies this as the "matrix of domination and system of oppression" that lies within the black/white paradigm. Calmore, supra note 8, at 64 .

44. 4 Cal. 399 (1854).

45. See id. at 404.

46. 11 Va. (1 Hen. \& M.) 134 (1806).

47. See Davis, supra note 41 , at 703 .

48. Professor Haney López discusses Ozawa v. United States, 260 U.S. 178 (1927), in which Takao Ozawa, a man of Japanese origin, claimed the right to naturalize based on his assimilated 
Blacks were also granted citizenship by the U.S. government, the prerequisite cases reveal that Asians attempting to define themselves as "white" may have wanted more than citizenship: By casting themselves as "white" rather than "black," they rejected the negative attributes and stereotypes associated with blackness.

Racialization by association with blackness and whiteness endures. Frank Wu has been most eloquent in discussing the ways in which Asian Americans have interacted with the black/white paradigm. In an article on affirmative action, Professor Wu writes that "[r]acial groups are conceived of as white, black, honorary whites, or constructive blacks." ${ }^{49}$ Professor Wu's choice of the words "honorary" and "constructive" expresses the poles of privilege and oppression. Asian Americans have stood on unstable ground between "black" and "white," falling under the honorary white category in anti-affirmative action arguments, but considered constructive blacks for the purposes of school segregation or antimiscegenation laws. ${ }^{50}$ To say that Asian Americans have been perceived as honorary whites or constructive blacks is, however, slightly misleading in that it tends to convey a notion of race specificity. It is important to keep in mind that although the status of honorary white does affect identity, recognition, and appellation, its more insidious function is cooptation. For example, within the economy of affirmative action policy, "whiteness" encompasses victimization through "reverse racism" and race-based disadvantage in certain educational or occupational opportunities. Insofar as a conservative like Newt Gingrich treats Asian Americans as honorary whites, ${ }^{51}$ he refers to common experience under affirmative action, not racial similarity.

In exploring the descriptive dimension of the black/white paradigm, I do not mean to ascribe a naturalness to the current race hierarchy. It is true that the black/white paradigm has played a leading role in shaping race discourse and ideology in the United States, and as such, it is not merely descriptive of a thing already in existence. As Professor Davis remarked, "[T]he black-white paradigm is an intriguing piece of white supremacy." 52 The black/white paradigm is derived from a racism that has created this particular hierarchy and method of race conceptualization. To that extent, the black/white paradigm not only posits that the Black-American race

lifestỹle and "white" skin color, and United States v. Thind, 261 U.S 204 (1923), in which Bhagat Singh Thind, a man of Indian origin, claimed the right to naturalize based on his "scientific" classification as "Caucasian." See HANEY LOPEZ, supra note 39, at 79-92

49. Wu, supra note 32, at 249.

50. See id. at 249-50.

51. See id. at 225 ("Gingrich has asserted that Asian Americans are facing a very real danger of being discriminated against because they are becoming too numerous at prestigious universities which have affirmative action." (citations omitted)).

52. Symposium, Race, Law and Justice: The Rehnquist Court and the American Dilemma, 45 AM. U. L. REV. 567, 615 (1996). 
experience is the paradigmatic race experience in the United States, but it describes the manifestations and systematic organization of racism as well.

\section{B. The Theoretical Dimension}

Breaking down the notion that the "black" and the "white" of the black/white paradigm are race-specific clears space for a refreshed understanding about racial stratification in the United States and the role of the black/white paradigm. It should be clear from the discussion so far that the paradigm is not simply race-specific. To be nonwhite is to be the other, and that other is constructed as black, regardless of where a particular individual or group comes from or what it looks like. ${ }^{53}$ The theoretical dimension of the black/white binary paradigm is perhaps most significant because of its clarity on the issue of domination and subordination. In the binary system, Whites "fashioned themselves as the superior opposite to those constructed as others." ${ }^{54}$ Those "others" have included various nonWhite races, but the fluidity or ambiguity of their positions within the black/white paradigm has sometimes served to cloud the bases upon which dominance and subordinance are conditioned.

The othered status of Asians was plainer in the last century and first half of this century. It was manifested in race-based exclusion laws, naturalization laws, and miscegenation laws. ${ }^{55}$ Asians' racially subordinated status was also socially and culturally evident: It has been said that the status that the White American preferred Asians to occupy was one of "biped domestic animals in the white man's service." ${ }^{56}$ The association between Asian and black was also more explicit in the last century: There has been important scholarship on the "negroization" of the Chinese and the attribution to the Chinese of characteristics formerly ascribed to Blacks, Black slaves in particular. ${ }^{57}$

In the latter half of the twentieth century, the subordinated status of Asian Americans has become obfuscated. The most obvious example of

53. It bears repeating that the category "White" is also constructed and that many of those individuals now classified as White were not White less than a century ago. See Madison Grant, The Racial Transformation of America, 219 N. AM. REv. 343 (1924) (lamenting the dilution of America's pure Nordic race). See generally MATTHEW FRYE JACOBSON, WHITENESS OF A DIFFERENT COLOR: EUROPEAN IMMIGRANTS AND THE ALCHEMY OF RACE (1998) (tracing the historical development of whiteness); HANEY LOPEZ, supra note 39, 106-07 (deconstructing the notion of a stable and monolithic White race and concluding that "[w]hite is what we believe it is").

54. HANEY LOPEZ, supra note 39, at 167.

55. See generally HANEY LOPEZ, supra note 39, at 79-109 (analyzing naturalization cases); OKIHIRO, supra note 37, at 50-52 (discussing exclusion laws and miscegenation laws).

56. HANEY LOPEZ, supra note 39, at 62 (quoting Chester Rowell, Chinese and Japanese Immigrants-A Comparison, 34 ANNALS OF AM. ACAD. 223, 224 (July-Dec. 1909)).

57. See id. at 51-52; OKIHIRO, supra note 37 , at $43-44$. 
this obfuscation at work is the model-minority myth, which has been embraced not only by White Americans in order to allege reverse discrimination, but to some degree by Asian Americans content to claim their superiority over Blacks and Latinos. ${ }^{58}$ Placing Asian Americans in the middle, however, does not necessarily mean that they are beyond or outside of the black/white paradigm. Asian Americans are now defined by their proximity to White conservative values and economic success as much as they were formerly compared to Blacks. The process of racialization and correlated valuation of individuals and groups occurs regardless of whether Asian Americans actually possess White or Black traits, whatever such traits may be. Professor Okihiro expresses this instability (and arbitrariness) in the following way:

Asian Americans have served the master class, whether as "nearblacks" in the past or as "near-whites" in the present or as "marginal men" in both the past and the present. Yellow is emphatically neither white nor black; but insofar as Asians and Africans share a subordinate position to the master class, yellow is a shade of black, and black, a shade of yellow. ${ }^{59}$

In light of the indeterminacy of "black" and "white," it is unclear what it means to go beyond the black/white paradigm. For Professor Perea, going beyond the black/white paradigm would mean the rejection of any type of race paradigm in favor of "the development of particularized understanding of the histories of each and every racialized group." ${ }^{60}$ But we have seen through the scholarship of Professors Haney López, Davis, and Okihiro that close examination of these groups' histories magnifies the ways in which the black/white paradigm organizes groups' social, legal, and racial identities and relationships in the United States. Although critics of the paradigm may condemn this method of organization, it is important to account for the fact that the paradigm may be a part of many people's selfunderstanding and experiences.

58. It would be naive to assert that Asian Americans are not tempted by the advantages of assimilation. Professor Calmore has observed:

I do believe ... that dominant America will attempt to situate Asians, Pacific Islanders and Latinos squarely within its efforts to determine who will be "white" in the twentyfirst century. ... It is a call to follow the European immigrant example of groups who, with each generation, have moved into a twilight ethnicity and paid the price of linguistic extinction and cultural loss for the privilege of white racial status.

Calmore, supra note 8, at 63-64 (internal quotations and citations omitted). Professor Wu has characterized the rise of Asian Americans as "a rise toward whiteness." Frank H. Wu, From Black to White and Back Again, 3 ASIAN L.J. 185, 212 (1996) (book review).

59. OKIHIRO, supra note 37 , at 34 .

60. Perea, supra note 8, at 1256. 


\section{The Political Dimension}

The black/white paradigm offers a robust, unequivocal understanding of the relationship between race-based domination and subordination. Its political dimension is closely related to its theoretical one in that a claim to blackness by Asian Americans can lead to coalition-building among people of color against white supremacy.

The notion of a coalition against white supremacy is forcefully articulated by Charles Lawrence, although, curiously, he rejects the black/white paradigm as "dysfunctional in a multiracial society" because it is "not first about the eradication of white supremacy." ${ }^{1}$ Professor Lawrence writes of the need for a theory that seeks societal transformation, a theory that "sees [racism's] injury as done to the collective, as suffered by us all." $62 \mathrm{He}$ unfortunately fails to explain why the black/white paradigm does not capture the spirit of the nonwhite collective "whom white supremacy ... relegates to varying degrees of inferiority." 63

Chris Iijima, on the other hand, identifies the potential of the black/white paradigm to accomplish the goals articulated by Professor Lawrence. According to Professor lijima, "deconstructing the old black/white paradigm carries with it new dangers.... The original paradigm, while constructing and reaffirming white dominance, also permitted a useful counter-focus on the effect and operation of white supremacy." ${ }^{64}$ In other words, to recognize the operation of white supremacy, we are forced to rely on the black/white paradigm. Professor lijima illustrates this proposition by analyzing the racialization of Blacks and Koreans during the 1992 Los Angeles riots:

It is significant to note that in the construction of the conflict, nativist arguments that Koreans were foreigners and less American positioned African Americans as "white" relative to Asians. On the other hand, Korean Americans were also placed within the entrepreneurial American Dream and positioned as white. This kind of positioning becomes coherent only if the assumptions of the old paradigm and the placement of whiteness within it are accepted as the operating framework. ${ }^{65}$

61. Charles R. Lawrence III, Foreword: Race, Multiculturalism, and the Jurisprudence of Transformation, 47 STAN. L. REV. 819, 826 (1995).

62. Id. at 825 .

63. Id. at 826 .

64. Chris K. Iijima, The Era of We-Construction: Reclaiming the Politics of Asian Pacific American Identity and Reflections on the Critique of the Black/White Paradigm, 29 COLUM. HuM. RTS. L. REV. 47, 69 (1997).

65. Id. at 70 (citations omitted); see also HANEY LÓPEZ, supra note 39, at 166 (explaining that during the Los Angeles riots, "Asians-as-victims-of-Black-violence came to stand in for 
Professor Iijima makes a subtle point here about the black/white paradigm. $\mathrm{He}$ argues that even as the paradigm forces us to speak about race experiences according to its vocabulary and not one of our own choosing, it also permits us to understand (and potentially counter) the deployment of white supremacy and privilege.

Professor lijima adds another important insight about the critique of the black/white paradigm. He argues that the current focus on "categories of difference" may have overtaken the "search for political commonality" among those raced as non-White. ${ }^{66}$ For Professor Iijima, the black/white paradigm helps forge political identities for people of color and allows a "reverse discourse" organized around antisubordination and antisupremacist ideology. ${ }^{67}$

The establishment of a strong antisubordination principle is especially important for Asian Americans because they are positioned in the "model minority" middle and could contribute knowingly or unwittingly to the further oppression of African Americans. This buffer position renders Asian Americans especially vulnerable to political manipulation or, even worse, can cause a blindness or amnesia among Asian Americans about discrimination they themselves face. To advocate a coalition among those people of color raced as "black" is not to declare that there are no interethnic conflicts or that the experiences of racism for Blacks, Asians, Latinos, and Native Americans are identical. ${ }^{68}$ Political alignment and acknowledgement of differences are not mutually exclusive; non-White people of color should "negotiate their common agendas," ${ }^{69}$ one of which must undoubtedly be a broad goal of antisubordination.

\section{The Historical Dimension}

To be sure, the antisubordination principle does not by itself justify the black/white paradigm; that principle could probably be expressed in many different ways. Reliance on the antisubordination principle to legitimate the black/white paradigm would be defeated by arguments offered by Professors Chang and Perea; those scholars may object to the very words "black" and "white" on the grounds that they are indicative of specific races to the exclusion of others. Even if "black" and "white" are not race-

Whites in the racial semiotics of Los Angeles, but Asians-as-victims-of-crimes were Black for the purposes of police protection in that same semiotics").

66. lijima, supra note 64 , at 55 .

67. See id. at 74 .

68. We ought to heed Professor Calmore's warning that "it is analytically and strategically wrong to exaggerate the degree of commonality among people of color." Calmore, supra note 8 , at 63 .

69. This phrase is used in John O. Calmore, Racialized Space and the Culture of Segregation: "Hewing a Stone of Hope from a Mountain of Despair," 143 U. PA. L. REV. 1233, 1263 (1995). 
specific, they may be so construed by people who write or read books on race, or by people who propose or make civil rights legislation. This result could be harmful to non-Black people of color because they may indeed end up marginalized from race discourse and remedies. The next three dimensions of the black/white paradigm that will be discussed-historical, poetic/linguistic, and subversive-will illustrate why the risk we take in preserving the black/white paradigm may be justified.

The historical dimension of the black/white paradigm first and most fundamentally refers to the Black-White struggle since the birth of this nation. The history of the kidnapping, enslavement, and subhuman treatment of Africans by White European Americans is simply the most vivid and terrifying example of white supremacy in American history. The black/white paradigm also serves as a constant reminder of the continued racial oppression of African Americans in the legal, political, and social arenas: mob violence culminating in lynchings, Jim Crow laws, and ghettoization, to name a few of the strategies of subjugation. At the same time that the black/white paradigm evokes this most notorious period in American history, it also recalls the civil rights movement of the 1950s and 1960 s and the battle to revolutionize the race hierarchy and power structure of the United States. It brings to mind the inspirational stories of Black activists like Martin Luther King, Thurgood Marshall, and Rosa Parks. In this way, the black/white paradigm not only highlights the longstanding racist ideology of the nation, but it also suggests tactical opposition to that ideology.

Exploring the changing nature and content of the black/white paradigm also offers insights into supremacist ideology as applied to non-Black races. As I have argued above, the paradigm now describes more than the Black and White races; it has developed to articulate a hierarchical vision of racial groups that includes Latinos, Asian Americans, and Native Americans. From this perspective, the black/white paradigm infuses a sense of continuity and "movement" to the civil rights work of non-Black people of color by revealing the ways in which these groups' histories intersect with the history of Black Americans. One example of historical intersection is the importation of Chinese laborers to replace slave labor during the Reconstruction Era. The Chinese were described as "more obedient and industrious than the negro, [able to] work as well without as with an overseer, and at the same time are more cleanly in their habits and persons than the freedmen." "This "praise" of Chinese laborers is revealing in that it: (1) places the Chinese in an intermediate position between Blacks and Whites; (2) denigrates Blacks further; and (3) subordinates the Chinese as

70. Wu, supra note 32, at 231 (citing to a newspaper quotation found in LUCY M. COHEN, CHINESE IN THE POST CIVIL WAR SOUTH: A PEOPLE WITHOUT A HISTORY 124 (1984)). 
the new "obedient" slave labor force in the place of Blacks. This example, cited by Professor Wu as the origin of the model-minority myth, ${ }^{71}$ demonstrates not only that Asian-American history cannot be divorced from the black/white paradigm, but that the legacy of the paradigm remains a vibrant part of contemporary Asian-American experience. Another clear moment of historical intersection is the Los Angeles riots, where the histories of at least three non-White racial groups intersected explosively. ${ }^{72}$

These historical examples affirm Neil Gotanda's observation that "[e]ven as the possibilities of racial stratification and the embedded ideological constructions of Orientalism are examined, awareness of the continuation of that basic axis of power and privilege [between Whites and African Americans] must continue." 73 Any analysis of racial oppression in the United States, including that of Asian Americans, has as its starting point the enslavement and continued subjugation of African Americans. From Hudgins ${ }^{74}$ in 1806 to the Los Angeles riots in 1992, White privilege and domination over non-Black people of color have been defined and organized within the context of the Black/White relationship. This relationship, as well as subsequent formations, has been expressed specifically through the black/white paradigm.

A failure to acknowledge the significance of the Black/White relationship and the origin of the black/white paradigm has repercussions for Asian American legal scholarship on race. ${ }^{75}$ When the acknowledgement is no more than a concession to recorded facts, AsianAmerican civil rights history itself flounders. Harold Koh, for example, has noted the absence of a sense of "movement" and continuity in the AsianAmerican civil rights struggle. ${ }^{76}$ Professor Koh's comment supports Professor Perea's argument because the absence of Asian-American civil

71. See Wu, supra note 32 , at 229.

72. Comparing the histories of Asian Americans and Black Americans is yet another way of understanding the methods of discrimination directed at Asian Americans. Exploring the paradoxes of being Asian American, Pat Chew describes how Asian Americans "have been victims of lynching, race riots, and slavery," methods of subjugation that are widely known to have been used to oppress Blacks. Pat K. Chew, Asian Americans: The "Reticent" Minority and Their Paradoxes, 36 WM. \& MARY L. ReV. 1, 9 (1994).

73. Neil Gotanda, Multiculturalism and Racial Stratification, in MAPPING Multiculturalism 238, 246 (Avery F. Gordon \& Christopher Newfield eds., 1996)

74. 11 Va. (1 Hen. \& M.) 134 (1806).

75. Professor Calmore states that most advocates of moving beyond the black/white paradigm would reject the importance of understanding Black-White racism. See Calmore, supra note 8 , at 64 n.212. Because there are a few scholars who acknowledge the need for understanding the Black/White relationship, see, e.g., Francisco Valdes, Foreword: Under Construction-LatCrit Consciousness, Community, and Theory, 85 CAL. L. REv. 1087, 1104 (1997) (cautioning against the failure to appreciate the "singular facts and histories that shape(d) the Black experience of slavery and subordination in this country"), and because scholarship that focuses on the black/white paradigm is so limited, I am not yet in agreement with Professor Calmore's view.

76. See Harold Hongiu Koh, Foreword to ASIAN AMERICANS AND THE SUPREME COURT, supra note 4 , at ix-x. 
rights history in casebooks and the law school classroom contributes to a "scattered" impression of that history. But this may also be in part due to a failure to recognize the historical intersections among Blacks, Asian Americans, Latinos, and other non-White people of color, leading to a decontextualized and scattered understanding of non-African American civil rights activism.

\section{E. The Linguistic/Poetic Dimension}

Another notable aspect of the black/white paradigm is the vitality of its vocabulary in race discourse. The exchange between the Judge and Steve Biko, as transcribed in Donald Woods's Biko (and quoted in the epigraph to Part III), illustrates the hermeneutics of the words "black" and "white." In attempting to understand the way in which Biko uses the word "black," the Judge suggests that "black" is an inaccurate description of the physical appearance of Africans. ${ }^{77}$ Biko's reply demonstrates that, in fact, the words "black" and "white" are pregnant with negative and positive meanings, respectively. ${ }^{78}$ Biko asserts that his embrace of the word "black" is aimed at the black man so that the word may be "elevate[d] ... to a position where we can look upon ourselves positively; because even if we [Blacks] choose to be called 'brown,' there will still be reference to 'blacks' in an inferior sense in literature and in speeches by white racists in our society." 79

Biko's response reveals three crucial insights. The first is that "black" and "white" have developed in opposition to each other in our language. This is not limited to political or racist language; as Biko observed, it exists in literary language. Examples abound: One of the more obvious would be Joseph Conrad's Heart of Darkness, where "black" stands for the sinister and unknowable. ${ }^{80}$ Setting aside whatever political views Conrad might have had, his novella could be interpreted as the story of a man whose descent into madness (and finally death) is caused by his liminal racial position in the jungles of the Congo. In this sense, the pairing of "black" and "white" is almost poetic; its apparent simplicity is, in fact, so expressive of difference and opposition that it approaches the visual.

The second insight is that the black/white paradigm is not one that we can escape through our own will. This indicates not only that we are raced but also that we are raced in specific terms, whether those terms be "black" and "white" or "Black" and "White." This has particular applicability to Asian Americans demanding a third category (perhaps "yellow") that

77. See Woods, supra note 36, at 165.

78. Steve Biko refers to the meaning of the word "black" in "black magic," "black market," and "black sheep of the family." Id. at 164.

79. Id. at 165-66.

80. JOSEPH CONRAD, HEART OF DARKNESS (Doubleday 1991) (1899). 
would capture their sense of difference from the black and the white. As Steve Biko observed, we can call ourselves "brown" or "yellow" until we are blue in the face, but it is unlikely that those terms will be adopted or will displace the vocabulary of the black/white paradigm successfully. ${ }^{81}$

Moreover, it is naive to assume that we can fully control the content of the words that we choose. This leads to Biko's third insight: Rather than attempting to create a parallel racial vocabulary, it may be more effective to undermine the content of the words white racism has chosen. This is a tactic that not only contains the element of surprise, but also explodes the assumptions embedded in the current, dominant vocabulary of race. Such explosions happen when Asians in England call themselves "black." 82 They also happen when Asians, Whites, and multiracials in South Africa call themselves "black." ${ }^{33}$ This tactic may also explain why the term "African American" is fading out of discourse: "Black" includes West Indians and Muslim Blacks who do not fit neatly under the category of "African American" but share similar experiences and feelings of solidarity. ${ }^{84}$

\section{F. The Subversive Dimension}

The discussion on the linguistic dimension of the black/white paradigm hints at the rich possibility of subversion. Subversion is, in my view, the only way that racialization will progress beyond the black/white paradigm to a discourse that will not only be more inclusive, but also more rational. Each of the different dimensions I have discussed in this Note contains this element of subversion.

The descriptive dimension of the paradigm serves as the foundation for the process of subversion. Scholars such as Omi, Winant, Haney López, and $\mathrm{Wu}$ have eloquently argued that race is a social and legal construction, and that race groups in the United States have been defined in relation to blackness and whiteness. This process has been most evident for Asian Americans, whose racial status has shifted from basically-"black" to almost-"white" over time. The black/white paradigm determines social status and denies free self-definition; this aspect of the paradigm is the most insidious because it creates a self-perpetuating race hierarchy in which the goal is to maintain the status quo for those situated at the top.

81. Professor Wu seems to join Steve Biko in skepticism about individual will and parallel understandings of race: "[Asian Americans] should not be so foolish ... as to believe that they can really exercise their individual decision or even their collective choice [to be accepted as white]." Wu, supra note 58, at 205.

82. See Robert S. Chang, The End of Innocence or Politics After the Fall of the Essential Subject, 45 AM. U. L. REV. 687, 691 (1996).

83. See Lawrence, supra note 61 , at 827.

84. See Black Is Back, THE NEW YORKER, Oct. 30, 1995, at 33. 
Understanding the black/white paradigm in this way means that Asian Americans can begin to grapple with both how racial identity is constructed and how it can be reconstructed. Such a step requires a critical analysis of the black/white paradigm as a mechanism that situates various racial groups within a structure that restricts access to privileges such as citizenship, education, and employment.

Recognition of the black/white paradigm as an iteration of race hierarchy brings into focus the overarching strategy of domination over all those categorized as "others." But even as the paradigm oppresses, it betrays a small opening for political counteraction in the form of Professor Iijima's "reverse discourse" ${ }^{85}$ and through the paradigm's inherent caricature of race relations within its descriptive dimension. This also leads to the possibility of coalition among people of color who share the antisubordination agenda. Moreover, the paradigm contextualizes the civil rights agenda, reminding us not only of historical race oppression but also of historical resistence against oppression, especially salient to those who share a sense of intersecting civil rights histories.

In at least one sense, Asian Americans possess greater opportunities to subvert race hierarchy and become agents of change than other people of color. Because Asian Americans have been situated as the model minority, they enjoy greater opportunities in education and occupation. Yet the model-minority status is problematic, especially as it contributes to the maintenance of racist polarity. ${ }^{86}$ In the same way that racial categories become destabilized when Asians call themselves black, a rejection of the model-minority status destabilizes racial relationships. This means first that Asian Americans who have achieved financial or political success through the black/white paradigm (and its own unofficial affirmative action) also have the means to effect change by using their position. Second, Asians can subvert race hierarchy by refusing to adopt the politically conservative views that are imputed to the model minority. Both of these decisions require a deep understanding of the black/white paradigm.

\section{THE ASIAN-AMERICAN CIVLL RIGHTS AGENDA: IDENTIFYING THE DIFFERENCES}

Banishing the black/white paradigm from legal scholarship disconnects it from Asian-American civil rights activism. On the other hand, confrontation with, as well as redeployment of, the paradigm by legal scholars has the potential to contribute to activism and further the civil rights agenda. Existing scholarship challenges this notion and argues that

85. See supra note 67 and accompanying text.

86. See supra notes 35,58 and accompanying text. 
the black/white paradigm does not fit the Asian-American experience or that community's goals. ${ }^{87}$ First, they argue that the discrimination experienced by Asian Americans follows not a color axis but a "foreigner axis." That is, whereas Blacks deal with second-class citizenship, a status repugnant to principles of American democracy, Asian Americans are viewed as outsiders to whom access is rightly denied. ${ }^{88}$ The assumption is that because Blacks are assumed to be American citizens, the demand for equal rights, opportunities, and privileges appears more legitimate than when immigrants demand those same things. Second, they argue that some of the most pressing civil rights issues concerning Asian Americans either do not concern Black Americans or affect them differently. ${ }^{89}$ The logical conclusion to this statement is that a race paradigm that fits the Black civil rights agenda may not necessarily fit the Asian-American agenda.

\section{A. Racism or Nativism?}

Angelo Ancheta's uses the term "foreigner axis" to explain subordination based on "racial" origin." Therefore, Asian Americans, Latinos, and Arab Americans are categorized as foreigners and immigrants, regardless of actual citizenship status or place of birth. Ancheta calls this mechanism "outsider racialization." "1 Outsider racialization closely resembles "nativism," a distinctive type of racism aimed at groups like Asian Americans, Latinos, and Arab Americans. Nativistic arguments about Asian Americans or Latinos are prevalent in political discourse-the controversy over Asian American contributions to the Democratic National Committee in 1996, ${ }^{92}$ Proposition 187 in California, ${ }^{93}$ the English-only movement,${ }^{94}$ and the myth of the Japanese takeover ${ }^{95}$ exemplify the power

87. See, e.g., ANGELO N. ANCHETA, RACE, RIGHTS, AND THE ASIAN AMERICAN EXPERIENCE 64 (1998) (arguing that the axis of the subordination of Asian Americans is not white versus black); Robert S. Chang, Dreaming in Black and White: Racial-Sexual Policing in The Birth of a Nation, The Cheat, and Who Killed Vincent Chin?, 5 AsIAN L.J. 41, 42 (1998) (noting that the paradigm treats Asian Americans as interlopers in race discourse); Tamayo, supra note 8 , at 23 (observing that the paradigm is inadequate).

88. See ANCHETA, supra note 87, at 62-81 (1998); John S.W. Park, Note, Race Discourse and Proposition 187, 2 MrCH. J. RACE \& L. 175, 188-90 (1996).

89. See, e.g., ANCHETA, supra note 87, at 161. These arguments are identical to three of Professors Omi and Winant's objections to the black/white paradigm. See supra note 19 and accompanying text.

90. See ANCHETA, supra note 87 , at 64 .

91. See id.

92. See, e.g., id. at 66 (describing the impact of the controversy over donations made by Asian businesses); James Sterngold, Political "Success" Leaves Many Asian-Americans Bitter, N.Y. TMES, Mar. 23, 1997, at 22 (same).

93. See infra notes $117-122$ and accompanying text.

94. See, e.g., ANCHETA, supra note 87, at 114-15 (describing various English-only campaigns). 
of nativistic sentiments in the American social and political consciousness. Nativism has, as Professor Chang notes, a certain allure because it tends to express racism and oppression in seemingly race-neutral terms such as "immigrants" and "foreigners." 96

Although nativism is one of the most salient aspects of Asian American experience, Professor Ancheta's argument that Asian Americans are not affected by the color axis seems overstated since nativistic arguments are aimed at those who are classified as non-White. ${ }^{97}$ This is why I believe that the term "outsider racialization" is superior to "nativism": It successfully conveys that race and national origin have been combined for discriminatory purposes. Thus, it is curious that Professor Ancheta denies the effect of the color axis in favor of the foreigner axis alone. The assumption of nativist-racists is that the United States is a White nation ${ }^{98}$ and that anyone who is not (or does not look) White is a foreigner. As Pat Chew has observed: "Like African Americans, Asian Americans' skin color and other facial features physically distinguish them.... As Justice Sutherland noted in United States $v$. Bhagat Singh Thind, ${ }^{99}$ it cannot be doubted that the children born in this country of Hindu parents would retain indefinitely the clear evidence of their ancestry." 100 Thus, nativism properly can be seen as a refined derivative of discrimination based on the color axis. ${ }^{101}$

Notwithstanding the significance of the color axis, the question remains whether outsider racialization "fits" within the black/white paradigm. The role of outsider racialization within the black/white paradigm can be more

95. See, e.g., Chang, supra note 8 , at 16 (describing the "spectre" of a Japanese takeover when Japanese companies make investments in the United States). This myth had deadly consequences for Vincent Chin, a Chinese American man beaten to death by two Detroit auto workers because he was mistakenly believed to be Japanese. See Chang, supra note 87, at 55 .

96. See Chang, supra note 8 , at 16 .

97. This was not always the case. Nativistic sentiment was rampant in the early 1900 s when immigration from Eastern and Southern Europe increased. The debate on restricting the immigration influx vacillated between biological arguments based on the racial inferiority of the new immigrants and social arguments based on their ethnic inferiority. See THOMAS ALEXANDER ALEINIKOFF ET AL., IMMIGRATION: PROCESS AND POLICY 52-54 (3d ed. 1995); Joe R. Feagin, Old Poison in New Bottles: The Deep Roots of Modern Nativism, in IMMGGRANTS OUT!: THE NEW NATTVISM AND THE ANTI-IMMIGRANT IMPULSE IN THE UNITED STATES 13, 19-26 (Juan F. Perea ed., 1997).

98. See Wu, supra note 58, at 194 (quoting PETER BRIMELOW, ALIEN NATION: COMMON SENSE ABOUT AMERICA's IMMIGRATION DISASTER 10 (1995), in which Brimelow suggests that "the American nation has always had a specific ethnic core. And that core has been white.").

99. 261 U.S. 204 (1923).

100. Chew, supra note 72 , at 34 (footnotes omitted).

101. Professor Haney López's analysis of the prerequisite cases also reveals how the foreigner axis does not work to the exclusion of the color axis, but rather in conjunction with it. See HANEY LÓPEZ, supra note 39, at 79-109 (discussing Ozawa and Thind, where Asians claimed to be racially White in order to naturalize); see also Wu, supra note 58, at 206 (remarking that Haney Lopez's White by Law "provides the crucial link between the analysis of race relations through a black-white paradigm and the treatment of Asian Americans under a citizen-foreigner paradigm"). 
clearly discerned by examining the way "reverse nativism" is used to discriminate against Black Americans. There is evidence that Blacks who have accents, and are thereby identified as immigrants or foreigners, are treated with less overt discrimination than Blacks who do not have accents. Malcolm Gladwell argues that the success of West Indians in New York, whom he compares to Korean and Chinese immigrants, is "one last, vicious twist" in the discrimination against Black Americans. ${ }^{102} \mathrm{He}$ explains that:

Their advantage depends on their remaining outsiders .... There is already some evidence that the considerable economic and social advantages that West Indians hold over American blacks begin to dissipate by the second generation, when the island accent has faded, and those in positions of power who draw distinctions between good blacks and bad blacks begin to lump West Indians with everyone else.

In the new racism, as in the old, somebody always has to be the nigger. ${ }^{103}$

While reinforcing the idea that "black" within the paradigm is not racespecific, reverse nativism sheds light on the interaction between outsider racialization and the black/white paradigm. Comparing the way in which outsider racialization is articulated against Black Americans in New York and against Korean Americans in Los Angeles, it becomes clear that it is deployed opportunistically between poles of blackness and whiteness. The treatment of Black Americans in New York also suggests that the history of White-on-Black oppression, as well as the accumulation of its signs, may inform the treatment of immigrant groups. It is also plausible to conclude from this example that the treatment of immigrants, in turn, informs the treatment of Black Americans.

Thus, to the extent that racial foreignness contains attributes of whiteness or of blackness, the paradigm captures the subordinated status not only of actual foreigners, but more aptly of permanent residents and citizens who happen to be people of color. This is the mode of analysis employed by Professor lijima in his analysis of the Los Angeles riots, ${ }^{104}$ and it can also be usefully employed to examine Proposition 187 in California. ${ }^{105}$ Nonetheless, outsider racialization perhaps does not achieve a perfect "fit" with the black/white paradigm because despite theoretical consistency, the application of the black/white paradigm to the foreigner 79.

102. Malcolm Gladwell, Black Like Them, THE NEw YORKER, Apr. 19 \& May 6, 1996, at 74,

103. Id. at 79,81 .

104. See supra note 65 and accompanying text.

105. See infra notes 117-122 and accompanying text. 
axis aspect of outsider racialization in the Asian American context remains somewhat counterintuitive.

\section{B. Items on the Asian-American Civil Rights Agenda}

The Asian-American civil rights agenda encompasses issues such as immigration, welfare, affirmative action, education, and suffrage. Although some of these issues (education, suffrage) coincide with those of the traditional civil rights movement, others (affirmative action, immigration) present newer challenges to civil rights activists.

\section{Affirmative Action and the Model-Minority Myth}

Asian Americans play a strange and contorted role in the affirmative action debate. Those who would eliminate affirmative action use the AsianAmerican population to exemplify how affirmative action disadvantages non-Whites as well as Whites. This is especially true for affirmative action in higher education, where some Asian Americans have been told-and have come to believe-that the program hurts Asian-American students' chances of attending certain universities. Newt Gingrich's warning that "Asian Americans are facing a very real danger of being discriminated against" has been heeded by many Asian Americans as evidenced in their voting pattern on this issue. ${ }^{106}$

Asian-American scholars have expressed concerns about the deployment of Asian Americans as the "example that defeats affirmative action." ${ }^{107}$ Frank Wu vigorously attacks the notion that banning affirmative action would actually help Asian Americans:

The real risk to Asian Americans is that they will be squeezed out to provide proportionate representation to whites, not due to the marginal impact of setting aside a few spaces for African Americans. The linkage of Asian Americans and affirmative

106. See Wu, supra note 32 , at 225 (quoting Gingrich at a press conference). Exit polls for California's Proposition 209 indicated that $39 \%$ of Asian American voters voted in favor of the anti-affirmative action measure. See Maria T. Padilla, Ties That Bind, ORLANDO SENTINEL, Oct. 4, 1998, at G1. Although I could not find statistics for Washington's Initiative 200, news commentaries suggested ambivalence among Asian American voters. See, e.g., Michael A. Fletcher, For Asian Americans, a Barrier or a Boon?; Washington State Debate over Affirmative Action Reveals Ambiguities on the Issue, WASH. POST, June 20, 1998, at A9.

107. Wu, supra note 32, at 225; see also Robert Chang, Reverse Racism!: Affirmative Action, the Family, and the Dream That Is America, 23 HASTINGS ConsT. L.Q. 1115, 1128 (1996) ("Asian Americans are told by conservatives that affirmative action hurts us."); Frank Wu, Affirmative Action: Divvying up the American Pie, LEGAL TIMES, July 3, 1995, at 26 ("The criticism of affirmative action draws on the model-minority myth."). 
action ... is an intentional maneuver by conservative politicians to provide a response to charges of racism. ${ }^{108}$

The discussion of affirmative action is most often bundled with the myth of the "model minority," which has been used to describe Asians in American society. Somewhat reminiscent of Edna Bonacich's groundbreaking sociological theory of the middleman minority, ${ }^{109}$ the model-minority myth works to divide the interests of subordinated racial groups. At the same time, it debilitates Asian Americans as individuals (Asians are brainy but lack personality) and as a political entity (Asians are successful and therefore not discriminated against).

The model-minority myth can be fruitfully analyzed within the framework of the black/white paradigm. As I have argued above, situating Asian Americans as a buffer between black and white does not position Asian Americans outside of the black/white paradigm, but rather in a vulnerable place where they can be manipulated to serve the interests of the dominant group. This is most likely what occurred in California when a large percentage of Asian Americans voted to eliminate affirmative action programs in the controversial Civil Rights Initiative of 1996. The myth also ultimately leads to further subordination of Asian Americans, especially by thwarting political mobilization, not only within the Asian-American population, but also across racial lines. The black/white paradigm can be used to help deconstruct the myth and clarify the subordinated position of Asian Americans in the race hierarchy. Only then can Asian Americans make informed political decisions and meaningfully pursue a civil rights agenda.

\section{Immigration}

The question of immigration is an especially volatile issue within the Asian American community. Although Gabriel Chin has argued that the immigration amendments of 1965 equalized immigration opportunities for Asians as compared with immigrants from the Western hemisphere, ${ }^{110}$ the resulting visible increase in the number of immigrants in the United States has precipitated a backlash from White Americans who seek to preserve

108. Wu, supra note 32 , at 226 ; $c f$. Gladwell, supra note 102 , at 79 . Gladwell notes:

The success of West Indians is not proof that discrimination against American blacks does not exist. Rather, it is the means by which discrimination against American blacks is given one last, vicious twist: I am not so shallow as to despise you for the color of your skin, because I have found people of your color that I like. Now I can despise you for who you are.

109. See Edna Bonacich, A Theory of Ethnic Antagonism: The Split Labor Market, 37 AM. SoC. REv. 547 (1972).

110. See Gabriel J. Chin, The Civil Rights Revolution Comes to Immigration Law: A New Look at the Immigration and Nationality Act of 1965, 75 N.C. L. REV. 273, 300-03 (1996). 
Anglo-American "culture." 111 Demographic anxiety has increased in the face of a growing number of people of color. According to a poll reported in the New York Times, White Americans believe that the population of Blacks, Asians, and Latinos in the United States is over twice as large $(50.1 \%)$ as it actually is $(24.4 \%){ }^{112}$

Demographic anxiety among White Americans can be relieved in two possible ways: The first is to restrict immigration of people of color, and the second is to oppress those people of color who are already in the country. ${ }^{113}$ Although both reactions stem from racism, they are distinct phenomena. Therefore, when Asian Americans speak of "immigration," a distinction must be made between immigration rights and immigrants' rights. ${ }^{114}$ The treatment of immigrants presents some serious civil rights issues because under equal protection doctrine, the recent laws that affect immigrants may violate the Constitution. ${ }^{115}$ One example of such laws is the welfare reform law of 1996, which denies many forms of federal assistance to legal immigrants and their children. ${ }^{116}$ Another example is Proposition 187 in California ${ }^{117}$ a measure that denies public education and all non-emergency medical care to undocumented aliens.

Proposition 187 provides fertile ground for analysis using the black/white paradigm. An initiative that was quite obviously directed against illegal immigrants from Mexico, Proposition 187 preyed upon nativist sentiments. Thus, much of the rhetoric of Proposition 187 focused on the idea that illegal immigrants were foreigners taking American jobs and benefits, entitlements belonging to legal residents only. ${ }^{118}$ According to John Park:

\footnotetext{
111. Wu, supra note 98 and accompanying text.
}

112. See Priscilla Labovitz, Immigration-Just the Facts, N.Y. TIMES, Mar. 25, 1996, at A15.

113. See ANCHETA, supra note 87 , at 85 .

114. The historical bias against Asians in immigration law is by now infamous. Immigration rights complicate the race issue in the United States because a powerful argument for state sovereignty can be made in defense of restricting immigration. The issue of open or fair immigration, while important, is beyond the scope of my Note.

115. See, e.g., Owen Fiss, The Immigrant as Pariah, in OWEN FIss, A COMMUNITY of EQUALS: THE CONSTITUTIONAL PROTECTION OF NEW AMERICANS 3-21 (1999) (arguing that laws imposing social disabilities on immigrants create social "pariahs" and violate the Equal Protection Clause).

116. See Personal Responsibility and Work Opportunity Reconciliation Act of 1996, Pub. L. No. 104-193, 110 Stat. 2105; see also Statement by President of the United States, 1996 U.S.C.C.A.N. 2891 (Aug. 22, 1996) ("I am deeply disappointed that this legislation would deny Federal assistance to legal immigrants and their children, and give States the option of doing the same."); Patrick J. McDonnell, Immigrants To Be Warned of Benefit Cuts, L.A. TMES, Feb. 1, 1997, at A1 (reporting on the removal of hundreds of thousands of legal immigrants from the Supplemental Security Income rolls).

117. 1994 California Voter Information: Proposition 187 (visited Feb. 23, 1999) <http://ca94.election.digital.com/e/prop/187/txt.html>.

118. See Park, supra note 88, at 177-78. 
Among people of color, the resentment toward undocumented immigrants was especially acute. Kevin Ross, an Inglewood deputy district attorney and political action chairman of the NAACP chapter of Los Angeles, noted that "[f]orty percent of African American youth are unemployed. When the assertion is made that illegal immigrants do the jobs others wouldn't do in the first place, the black community is offended." 119

This reaction was not limited to African Americans; many Asian Americans and Latinos voted in support of Proposition 187. 120 The strategy behind Proposition 187 successfully positioned legal residents as "white" relative to illegal immigrants because legal residents possessed the rights to work, to go to school, and to receive medical care.

Proposition 187 should also be understood as a case of outsider racialization against more than just the illegal immigrant community in California, although that community is certainly the law's primary target. The "xenophobic climate" created by Proposition 187 also affects entire Latino and Asian-American communities because of its tendency for overinclusiveness. As many civil rights workers and scholars have already noted, one major problem with Proposition 187 is its "unintended" effects on all people of color who look or sound foreign. ${ }^{121}$

But extremist propaganda in support of the Proposition also makes it clear that the issue was not limited to illegal immigration but intertwined with race and white supremacy:

Two days before the November 1994 elections ... flyers were distributed ... depicting an image of a machine gun firing bullets at a dark skinned man. The flyer reads: "How's this for a new slogan for the U.S. Border Patrol? 'If it ain't white WASTE IT!' Remember, it's stop the Mudslide ... or drown! 187 Yes! We need a real border. First we get the spics, then the gooks, and at last we get the niggers. They're all going home." ${ }^{122}$

There can hardly be a clearer representation of the active dichotomy that informs race discourse today.

119. Id. at 178 .

120. According to Park, 22\% of Latinos and almost half of all Asian American and African American voters in California voted in favor of Proposition 187. See id. at 185.

121. See, e.g., Nancy Cervantes et al., Hate Unleashed: Los Angeles in the Aftermath of Proposition 187, 17 ChICANO-LATINo L. REv. 1, 10-20 (1995) (describing incidents of hate crimes); Park, supra note 88, at 179-85 (noting protests against the measure).

122. Cervantes et al., supra note 121 , at 6 . 


\section{CONCLUSION}

The increasing visibility of people of color and the much-discussed demographic predictions for the next millenium have led to increased debate about race, law, and resources in the United States. And it is probably safe to conclude that the call for a more complex theory of race relations-one that better incorporates various people of color-has been heeded by the mainstream. This is most lately exemplified by President Clinton's race initiative.

This Note, however, has sought to demonstrate that the black/white paradigm is a complex theory of race relations and should be recognized as such. An understanding of the paradigm's six dimensions (and there may be more) reveals its capacity both to contextualize race discourse and to express a clear antisubordination agenda. Moreover, the paradigm's persistence in race relations and discourse attests to its continuing relevance and growing complexity. Asian-American scholars must resist the temptation to oversimplify or underestimate the paradigm's ability to perpetuate and refine itself by erasing histories, manipulating racial status, and dividing political alliances. Indeed, an alternative theory cannot emerge unless people of color dismantle the current organization and vocabulary of race, which have been articulated through the black/white paradigm. 